\title{
INTERPRETATIVE PROBE INTO CONTEMPORARY SLOVAK INDEPENDENT THEATRE. THEATRE PÔTOŇ: PASTORAL SYMPHONY
}

\author{
MIROSLAV BALLAY \\ Department of Cultural Studies at the Faculty of Arts, \\ Constantine the Philosopher University in Nitra
}

\begin{abstract}
The text explores the work of the independent Theatre Pôton - the only professional theatre in Slovakia to reside in the countryside. Using an interpretative approach within the process of communication, the study presents the work of the stage director Iveta Ditte Jurčová who works in tandem with the dramaturge and script writer Michal Ditte. The authors put the elements of multiple genres and intertextuality in their productions, whilst also employing alternative methods to work with words and/or verbal component. The material presents dominant, constant features of their poetics through their latest production Pastierska symfónia [Pastoral Symphony] (2019). ${ }^{1}$
\end{abstract}

Key words: theatre, periphery, stage production, Theatre Pôtoň, residential sabbatical, reenactment

The theatre Divadlo Pôtoň (hereafter Theatre Pôtoň) is by now a well-established professional independent theatre with a wide range of activities. It is unique not only because it is based in the countryside, but also thanks to the nature of the stage poetics of the team of authors - stage director Iveta Ditte Jurčová and dramaturge, script writer and playwright Michal Ditte. Their originally amateur company gradually devolved into an independent professional theatre. Since 2008, the theatre is based in the town of Bátovce, within the district of Levice in south-western Slovakia, ${ }^{2}$ together with the Centre for Arts and Creativity ${ }^{3}$. The stage director Iveta Ditte Jurčová explains the voluntary departure from the city and settling in the countryside as follows: "I find the quest for the art cathartic. It is like setting off on a pilgrimage, reach-

${ }^{1}$ Michal Ditte - Iveta Ditte Jurčová: Pastierska symfónia [Pastoral Symphony]. Dramaturgy Marek Godovič, libretto Michal Ditte, Iveta Ditte Jurčová, Katarína Caková, movement coach Robo Nižník, music Ivana Mer \& Cristian Estrella, production Monika Škojcová, Michal Ditte, lighting design Michal Ditte, visual concept Katarína Caková, Iveta Ditte Jurčová, visual production Katarína Caková, technical production: Horácke divadlo Jihlava, Hliníkové konštrukcie, s. r. o. - costumes production: theatre Horácke divadlo Jihlava, Elena Matová. Cast: L'ubomír Bukový/Filip Jekkel, Ela Lehotská, Robo Nižník, Natália Puklušová, Lubomír Raši. Premiered on 13 April 2019, Theatre Pôtoň, Bátovce.

${ }^{2}$ In 2000 - 2001 the Theatre Pôtoň was based in Zlaté Moravce, from 2001 in different venues in Levice, in 2008 it made its home in Bátovce. The town is located in the crossroads of three districts - Levice, Banská Štiavnica, Zvolen.

${ }^{3}$ The aim of the project of the Centre for Arts and Creativity is to increase quality of social, cultural and intellectual life in the region through presentation of contemporary life, workshops and discussions about contemporary arts, to develop critical thinking in high school and university students, to train future creative artists, cultural operators and theorists during professional workshops, to support creative artists in the field of contemporary non-commercial art through residential sabbaticals. Further information at https:// www.poton.sk/centrum-umenia-a-kreativity/. 
ing the goal and, after the journey hardships, experiencing something spiritual." ${ }^{4}$ Ditte Jurčová's directorial poetics is determined by the close connection with a specific rural context which she finds exceptionally inspiring. In order to be thoroughly familiar with the place, her works mostly draw on research or theatre lab.

Moving to the countryside, into an abandoned culture centre on the periphery of peripheries, was related to the Dittes' inclination towards a free creation based on an independent platform. Their work is illustrative of how the location of a theatre can affect dramaturgy of the themes addressed. By moving away from the capital city and from larger regional centres, the authors came to face altogether different types of current problems that are manifested in the countryside in their naked, stripped form. Another value added of such a space is an opportunity of a focused creative regime - from research of a given theme all the way to rehearsing in literally lab conditions. To rehearse in the regime of a periphery lab work is no easy task. Hence, the work of such independent theatre resembles somewhat an artistic residential sabbatical. The readiness to collaborate with the theatre entails giving up the comfort and benefits of the city. On the other hand, working on the periphery offers vast opportunities of isolated creative work and research in a virtually free independent regime which is often absent when rehearsing in other types of theatres. The purpose of an established independent culture centre and theatre lies in the principle of artistic residency, and in the exploitation of the educational role of theatre and/or the understanding of theatre as the place that saturates diverse scope of wider messages and missions within society, including learning and continuous public education.

The work by Iveta Ditte Jurčová shows different types of textual source (literary source text or plays), as well as the author's own productions with a striking signature script style of Michal Ditte that draw on the research within the platform (Terra Granus, Psota [Poverty] etc). The Slovak theatrologist Nadežda Lindovská argues that "The stage director Ditte Jurčová develops a distinct lyrical-grotesque poetics; she is open to new stage impulses. In tandem with Michal Ditte, the two authors are inspired by methods used in documentary theatre. They staged a series of productions reflecting historical memory of the place, drawing on the theme research." ${ }^{5}$

Ditte Jurčová has become an experimenting stage director. She does not hesitate to venture into lab/research) work. She often choses uneasy, intense, even thrilling path. It is not the text that she finds to be the key component of productions: instead, she prefers their visual language. She often works with cosmic elements, using their powerful visual artistic potential which she bases on an intentional extremity and over-exposure. She creates visual concert compositions, sometimes in between an installation, visual art composition, intermediality or multigenre approach. Her signature style lays in crossing the limits of theatre in order to venture out to other types of art and poetic genres. Yet she builds her language largely on visual parameters of her own unusual imagination.

${ }^{4}$ DITTE, M. - DITTE JURČOVÁ, I. - GODOVIČ, M. Bermudský trojuholník v Bátovciach: sila strácania a objavovania [The Bermuda triangle in Bátovce: The Power of Loss and Discovery, an interview]. In kød, 2019, Vo. 13, Issue 5, p. 11.

${ }^{5}$ LINDOVSKÁ, N. K otázke ženskej divadelnej réžie. Náčrt stavu a perspektív [On Female Theatre Directing. An Outlive of the Status Quo and Perspectives]. In PODMAKOVÁ, D. (ed.). Generačné premeny a podoby slovenského divadla (od 80. rokov 20. storočia po dnešok [Generational Transformation and Shapes of Slovak Theatre (from 1980S to the Present Day]. Bratislava : Ústav divadelnej a filmovej vedy SAV, 2012, p. 87. 


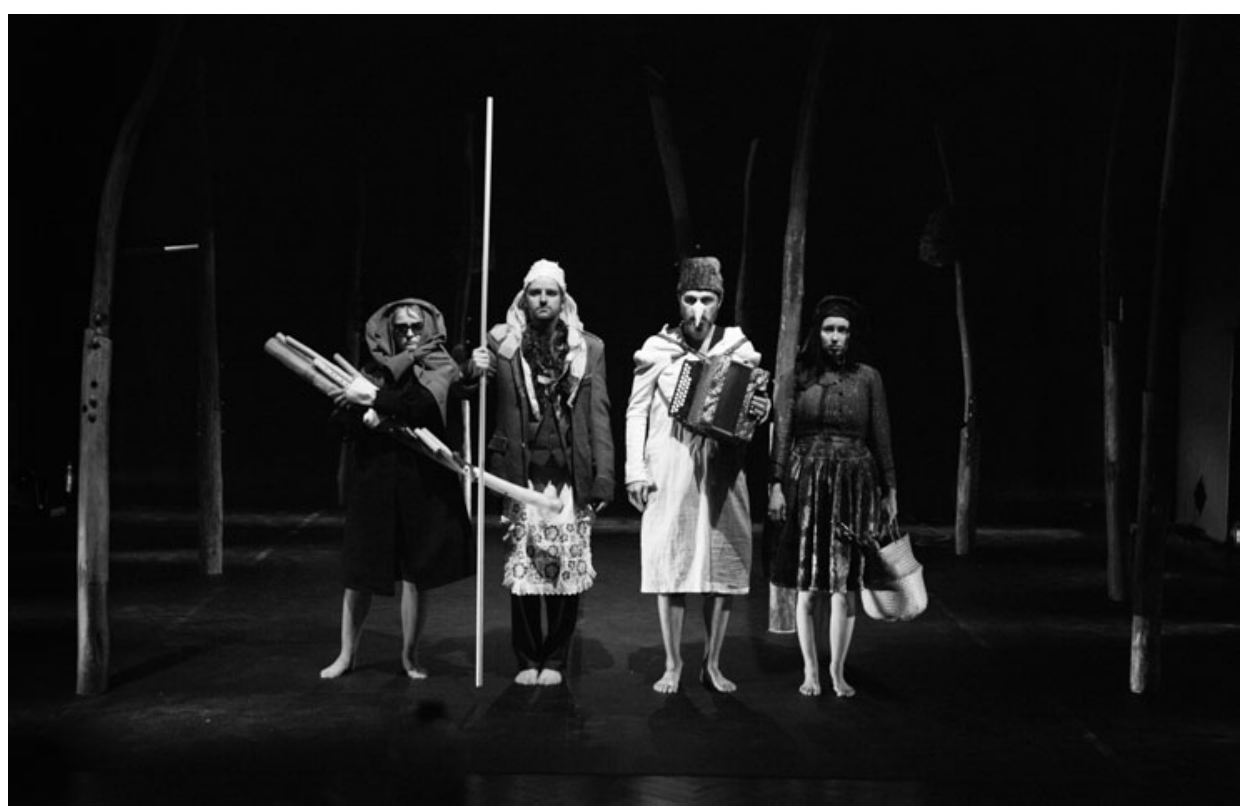

Team of authors: Pastoral Symphony. Theatre Pôtoň, Bátovce, premiered on 13 April 2019 in Bátovce. Direction Iveta Ditte Jurčová. From left Ela Lehotská (Mother), L’ubo Raši (Michal), Róbert Nižník (Ondrej), Natália Puklušová (Eva). Photo by Radovan Dranga. Theatre Pôtoň archives.

\section{Pastoral Symphony - a reenactment of reception experience}

The latest piece by the team Iveta Ditte Jurčová - Michal Ditte, the stage essay Pastierska symfónia [Pastoral Symphony, 2019], follows directly from their award-winning production Americký cisár [The Emperor of America, 2018] ${ }^{6}$, stage adaptation of the 2010 novel by Martin Pollack. Whilst The Emperor of America reflected emigration (the subtitle of the literary source is Masový útek z Haliče [Great Escape from Galicia], the latest stage essay brings forward the issue of repatriation as a dominant story archetype in the $20^{\text {th }}$ century Slovak drama literature. It contains discernible elements from Bačova žena [The Shepherd's Wife] by Ivan Stodola (1928), as well as additional variations of the emigration theme in literary works. Analogous motives appeared, for instance, in Čapek's novella Hordubal that served as a secondary literary source for the stage production Sclavi/Emigrantova píseň [Sclavi/The Song of the Emigrant, 2005] of the international theatre studio Farm in the Cave. Coincidentally, the character of the repatriating émigré in Pastierska symfónia [Pastoral Symphony] and in Emigrantova píseň [The Song of the Emigrant] is played by the same actor - Róbert Nižník. ${ }^{7}$ The dramaturge Marek Godovič explains in the production bulletin: “(...) the stage es-

${ }^{6}$ In the DOSKY 2018 poll the production received the Best Production in the 2018 Season Prize. It also received the Special Jury Prize for visual concept of the production that went to Iveta Ditte Jurčová and Katarína Caková at the festival Nová dráma/New Drama 2019.

${ }^{7}$ See further BALLAY, M. Farma v jeskyni [Farm in the Cave]. Nitra : Ústav literárnej a umeleckej komunikácie FF UKF v Nitre, 2012, p. 110. 
say Pastoral Symphony emerged from the themes offered by the $20^{\text {th }}$ century Slovak drama classic The Shepherd's Wife that is set in the context of the valley Demänovská dolina. The story of the characters in Stodola's repatriation drama is transformed in the composition by the Theatre Pôton into the stream of associative images of national and cultural identity, mythology, and collective memory. A short local legend is transformed into a civilisation report. (...) The reenactment of the past overlaps with an analysis of the present day; the old defragmented story serves as a backdrop to confront the present." 8

The leitmotif in Pastoral Symphony is the return of Ondrej Muranica home from America. The man who was trapped in the mines of Pennsylvania after a mining disaster, is believed back home to be either missing or dead. Whilst his mother is tormented by the loss of her son, his wife Eva faces a major dilemma: Is she to remain faithful to her missing husband or to marry his best friend Michal? She reaches for the second option. Hence, when Ondrej regains memory after five years and returns home, he finds Eva being married to Michal. In Pastoral Symphony the fatal comeback of the 'Americano' means the return of the dead (and/or the resurrection of the dead), someone who had been cried over by the hired weeper as is done in some funeral rituals. The Albanian author Ismail Kadare, who links funeral to the emergence of Antique tragedy, argues that the climax of a funeral arrives at the point when the deceased is laid to rest in the soil: "The dug-out grave or, better said, the pile of soil surrounding the grave is no doubt the first scene in tragic theatre. (...) The lead character in the course of events, the deceased, is placed, for the first and last time, in between two hostile kingdoms. He is the central character for a number of reasons imaginable, essentially because he no longer speaks. It is others who must speak, they must speak about him. And the others are - more than parents, wife, children, the kin of the deceased - women-weepers performing the ritual. The weepers are the primal kernel of an ancient chorus (...) In other words, just as the ancient chorus defended tragedy against the crowd of spectators, the weepers defend the funeral ritual against the relatives and, at the same time, against all the grieving."

The members of Pastoral Symphony production team made it their priority to work with the themes of multiple story archetypes. By reducing the text of the dramatic, literary source text, they explored different interpretative possibilities of staging. They did not intend to stage The Shepherd's Wife, but rather to present the pastoral colour with some flashes, allusions to the dramatic work at the intertextual level. Their approach to the dramatic source text could be identified as essential. The stage director did not compose precise mise en scènes in a deliberated directorial strategy. Instead, she used the principle of emergence and/or gradual emergence of scenes. Her reproduction is based on a fairly blurred associativeness which calls for a description of more coherently captured (perceived) scenes and their meanings. Using phenomenological approach to theatre art piece and following Dietrich Steinbeck, one can distinguish three layers:

${ }^{8}$ Pastierska symfónia [Pastoral Symphony]. Production programme booklet. Bátovce : Divadlo Pôtoň, 2019, not paginated.

${ }^{9}$ KADARE, I. Aischylos, ten vel'ký smoliar [Aeschylus, the Great Schlemiel]. Bratislava : Kalligram 2006, pp. $21-22$. 
a) that of real meaning;

b) of intended meaning;

c) of imaginary meaning. ${ }^{10}$

In accordance with the above three layers, the following text will also explore the issues of the perception of a theatre piece in terms of the creation of its imaginary meaning which in the spectator's perception grid expands from a foggy ephemeral nature of the language of associations offered by the authors. Therefore, the following passage presents the storyboard of the production that became the foundation for a continual improvisation with selected themes. Collective acting often gave rise to a play with layering images. Their chaining in a kind of succession was related to a marked associativeness of the stage piece.

The stage essay Pastoral Symphony opens with a scene engulfed in dimmed light. From an opaque smoke screen there emerge wooden posts that are hammered into the stage floor. Their quite symmetric arrangement enhanced the gloomy atmosphere of the acting area. The towering stumps of wood logs not only looked strange, but also, in combination with the gloom and the forest sound of birds, created the first associative image. The dense opaque smoke suggested an initial basis for the emerging 'symphony' of images and sounds. ${ }^{11}$

The original pastoral element entered into the production through the subsequent scene of an abstract, indifferent character wearing a white mask. The man carried out the slaughter of a sheep (a lamb) which in a number of religions embodies sacrificial beast. Ultimately, he stabbed the knife to corner wooden log on the stage. This non-verbal scene featuring an actor wearing a mask spread out an associative thread that wound through the entire production. ${ }^{12}$ The actors together kept developing the pastoral theme in subsequent scenes, whilst reviving the pastoral element largely through music, instrumental variations (music by Ivana Mer \& Cristian Estrella). They thus presented, for instance, the unique orchestral pastiche of sounds of different aerophones (pipes, fuyaras, etc.), thus vibrating relational passions in selected acting scores. The rich colours of sounds also evoked the mystery of the magical ornaments of the pastoral colour scope. The lashes of birch or different sounds of pipes brought on stage archaic roots of music folklore.

Amidst the havoc of unusual tones and sounds, suddenly four characters, dressed in picturesque costumes, drew close one to another arranged in an array. Their outfits referred to the comic nature of carnival scenes, thus bringing together a whole range of seemingly disparate costume elements. Each outfit featured some theme from folk suits: a cap, apron, undershirt, etc. Along with the curious combination of costumes, the carnival bunch was completed by musical instruments as each actor created an authentic sound by playing a music instrument. An extravagant lady in a long coat with mysterious sunshades and a veil loosely thrown over her head and tied around her neck held, throughout the scene, a fuyara and a number of ad-

\footnotetext{
${ }^{10}$ BALME, Ch. Úvod do divadelnej vedy [Introduction to Theatre Studies]. Bratislava : Divadelný ústav 2018, s. 104.

${ }^{11}$ From etymological perspective, symphony is best characterised by harmony, alignment and/or consonance in cyclical orchestral composition.

${ }^{12}$ As has been mentioned earlier, the production team addressed pastoral element (through sheep farming), into which they incorporated individual inputs of symphonically composed poem.
} 


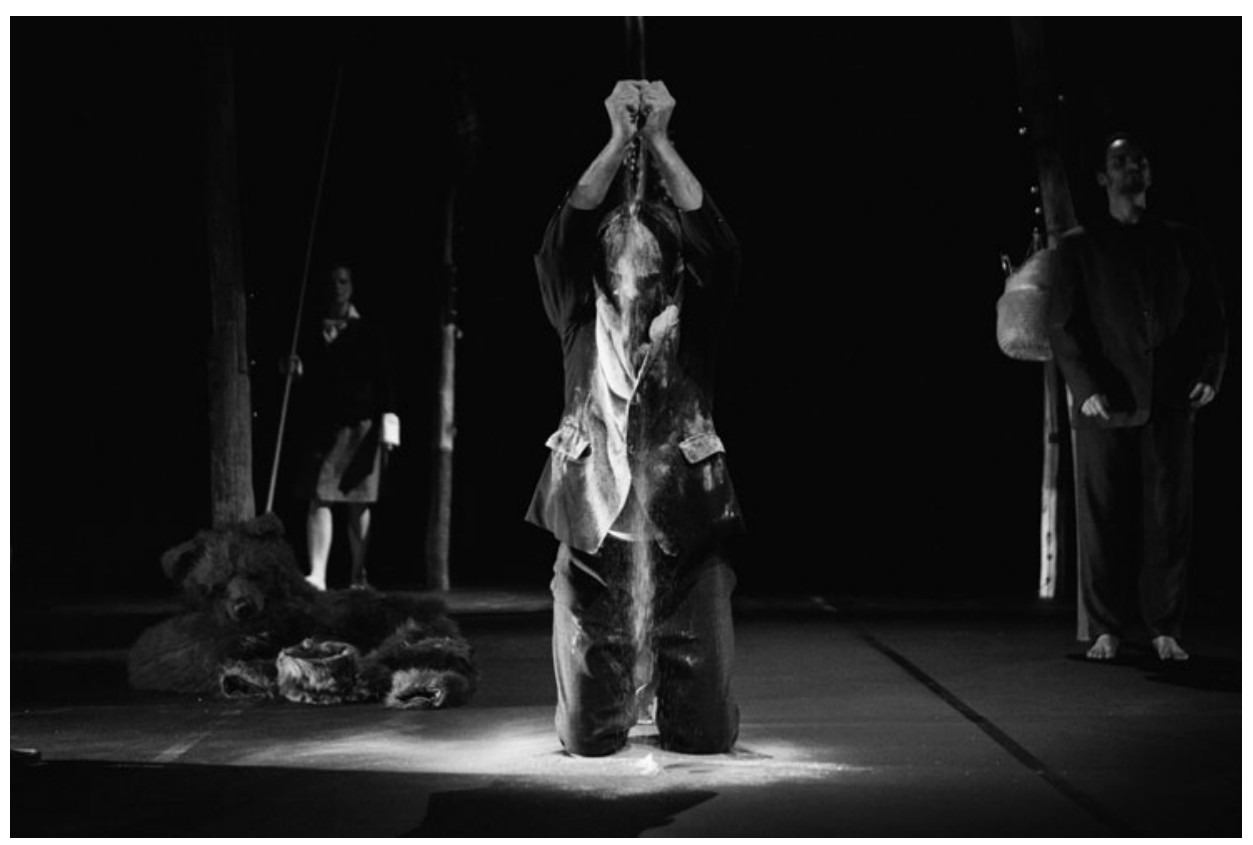

Team of authors: Pastoral Symphony. Theatre Pôtoň, Bátovce, premiered on 13 April 2019 in Bátovce. Direction Iveta Ditte Jurčová. From left Ela Lehotská (Mother), Róbert Nižník (Ondrej), Lubo Raši (Michal). Photo by Radovan Dranga. Theatre Pôtoň archives.

ditional pipes. A grotesque man in a costume that brings together male and female attributes presented the frequent prototype of carnival characters. ${ }^{13}$ With a white cap on his head, wearing male trousers, a number of jackets and a female apron, he embodied bisexuality and/or intersexuality of the carnival repertoire. Another example of the carnival grotesqueness was an actor in a white night gown with a fur-cap and a prominent beak instead of a nose. Even this was the case of matching the non-complementary, i.e. the bizarre combination of man and the beast. His comic appearance is complemented by an accordion the actor was pulling. And, finally, the component of the fourth actress was a string instrument attached under her chin as if it were an integral part of the character.

The next scene embodied elemental nature. It featured an actor realistically portraying a bear - all dressed in a dummy made of bear skin. Similarly to Ivan Stodola in his play, in this case the authors also used the bear theme. They first attenuated the beast in presence of wind instruments and powerful swashing. An intensive moment occurred only when Eva danced around the bear that was analogically linked to Ondrej. ${ }^{14}$ Then she put on the bear costume, assuming the attributes of the beast,

${ }^{13}$ As part of carnival processions not only men often dressed as women and vice versa, but the parades also featured a curious combination of masks of characters with dual gender features, and sometimes other zoomorphic and anthropomorphic characters.

${ }^{14}$ This parallel also becomes obvious in the dramatic source text, when Ondrej's mother compares him to an ogre. MOTHER: „Tvoj otec, to bol chlap - ozruta, a nebál sa nikoho..." ["Your father - the man he was 


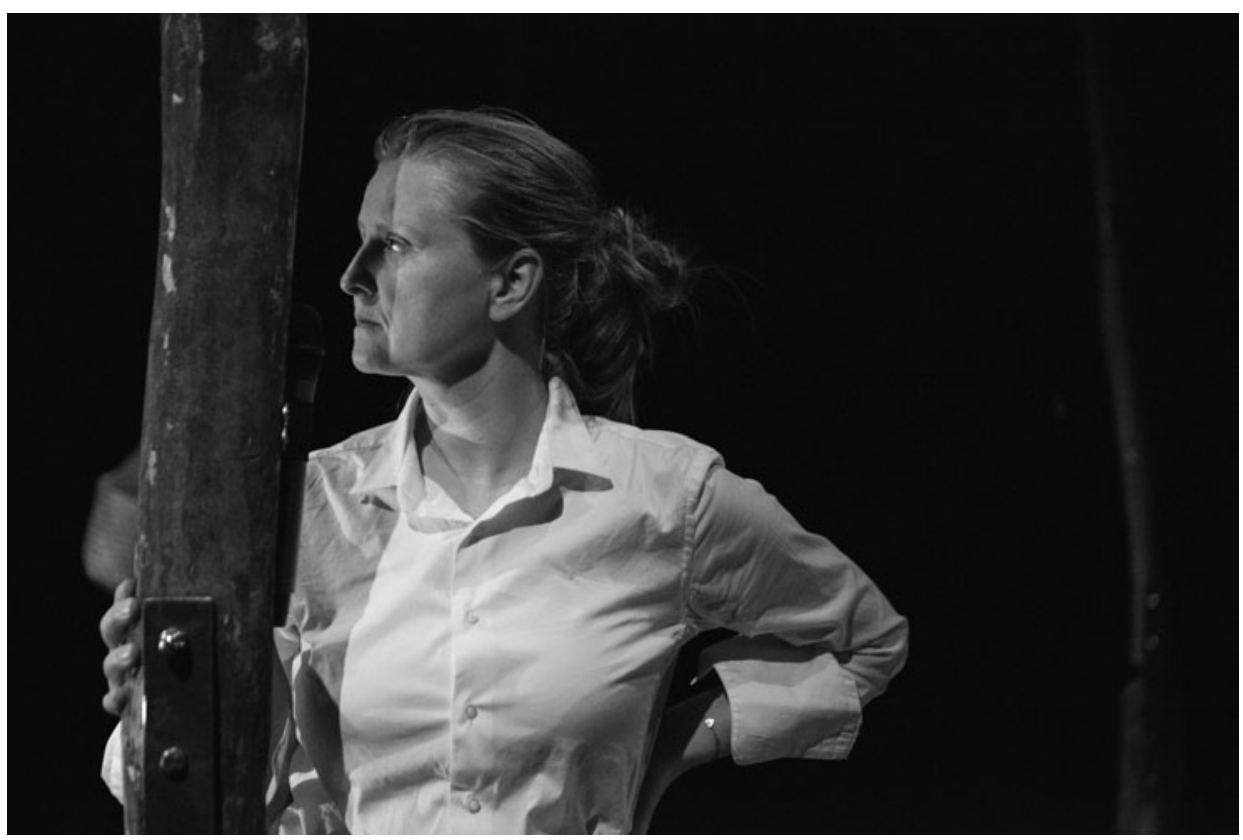

Team of authors: Pastoral Symphony. Theatre Pôtoň, Bátovce, premiered on 13 April 2019 in Bátovce. Direction Iveta Ditte Jurčová. Ela Lehotská (Mother). Photo by Radovan Dranga. Theatre Pôtoň archives.

along with its powerful sexual symbolism. The bear as a symbolic sign acquired the meaning of natural instinctiveness.

Even desperate cries of Eva, the mother, for her children, were instinctive by nature. Meanwhile, the actor portraying Eva's husband kept monotonously lifting and tipping a wooden board. This routine activity obviously signalled the labour tragedy of the émigré. His being trapped in the mine was expressed by dust that the actor kept throwing on his head. The image also carried the meaning of Ondrej being buried in the mine. In the meantime, his wife was calming her two children. They were created by the miniatures of sleeping children's heads wrapped in bird nests that were until then hanging on the wooden pillars (trees). She drew them to her bosom as a chick does to her offspring and brought them to sleep with lonely lullabies. In the background of the acting space Ondrej's mother was hovering over the lying body of the allegedly deceased son (the actress was supported from the back by another actor dressed in black, thus creating an illusion of the woman levitating). The scene closed with a recording of a real-life weeper. Her cry "My Son! My sovereign!" evoked authentic atmosphere of death. The intensity of the experienced pain that was incorporated into the recorded weeper song and also, for instance, in the expressiveness of the lullabies, was suddenly replaced by the sound of train. That was interlaced by a Jewish psalm for the victims of the Shoah, accompanied by a dance of all per-

- an ogre, and he feared no one..."]. In STODOLA, I. Bačova žena [The Shepherd's Wife]. Bratislava : Tatran, 1978, p. 15. 


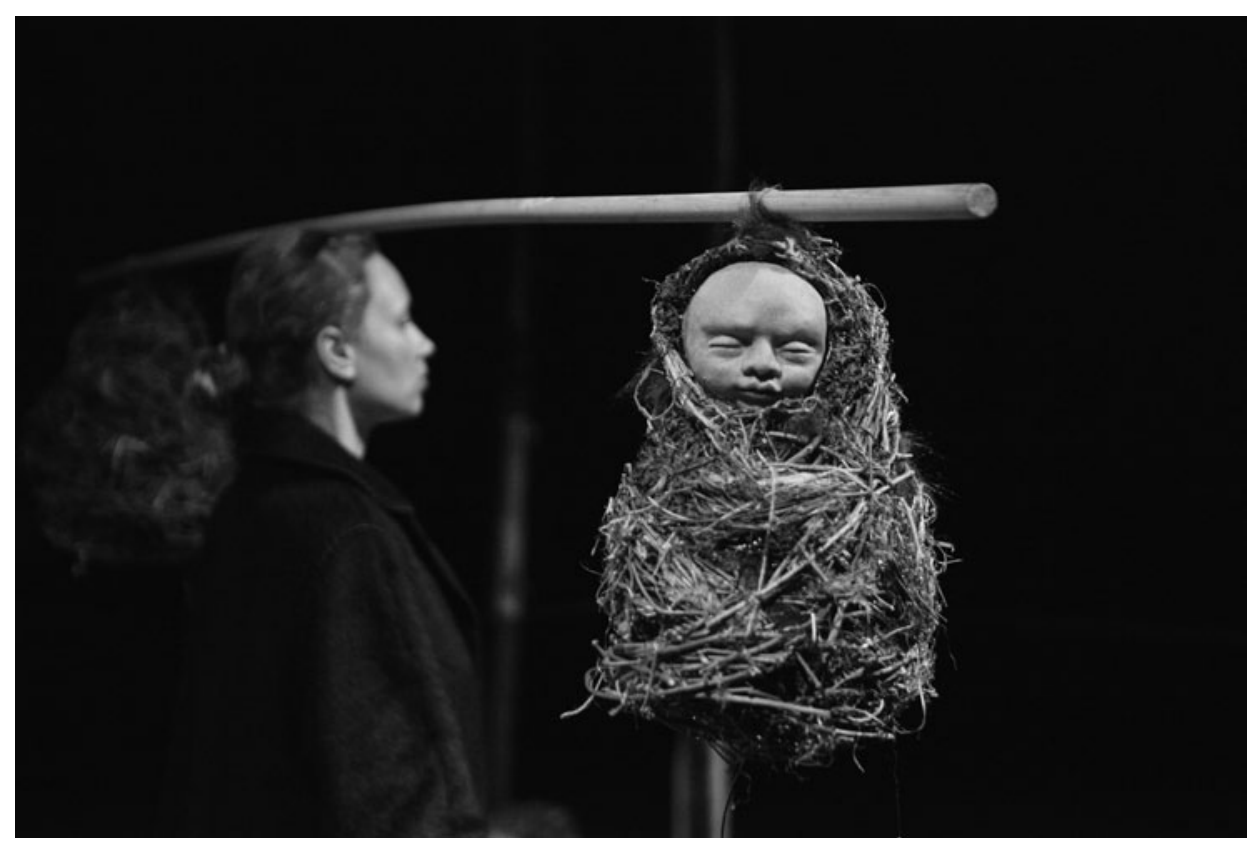

Team of authors: Pastoral Symphony. Theatre Pôtoň, Bátovce, premiered on 13 April 2019 in Bátovce. Direction Iveta Ditte Jurčová. Natália Puklušová (Eva). Photo by Radovan Dranga. Theatre Pôtoň archives.

formers. They rhythmically rumbled around, concentrated in different parts of the space. Heartbreaking names of concentration camps echoed in counterpoint to the sounds of the Jewish singing: Theresienstadt, Majdanek, Sachsenhausen, Birkenau, Auschwitz, Nemecká, Kremnička (...).

Some contrast to this funeral expressiveness was brought by the character of the seed merchant who carried a tiny house on his back. When he squatted and unfolded the house, it became a kitchen table. All it took to create an image of a family table where all characters gathered in mutual confrontation. The team staged the dead-end situation using the means of comic-desperate powerlessness. Actors were bringing salt close to their eyes and symbolised dropping tears by pouring down salt crystals. The scene of the painful conflict acquired at times even comic, anti-illusory level. The tension grew dense when the returned émigré Ondrej claimed his marital and parental right - the change occurred from ignorance to wisdom (Greek anagnorisis) as in drama with Antique ground plan. Since Ondrej lost his memory in America and had not been in touch with Eva for five years, the family had to come to terms with his death. On return, realising the truth was harsh: there was a need to come to terms with the given situation. In the situation, no one could be blamed.

In the closing scene, the polyphonic ancient Slavic Lord's Prayer was of a cathartic nature. Eva with a garland on her head placed two nests with her children on each side. In the background, in counterpoint to the image, the duel of rivals in love took place: Ondrej and Michal fought with knives in their hands. In the end, the knife like a flying murder instrument slipped down the declining invisible rope. It got reso- 


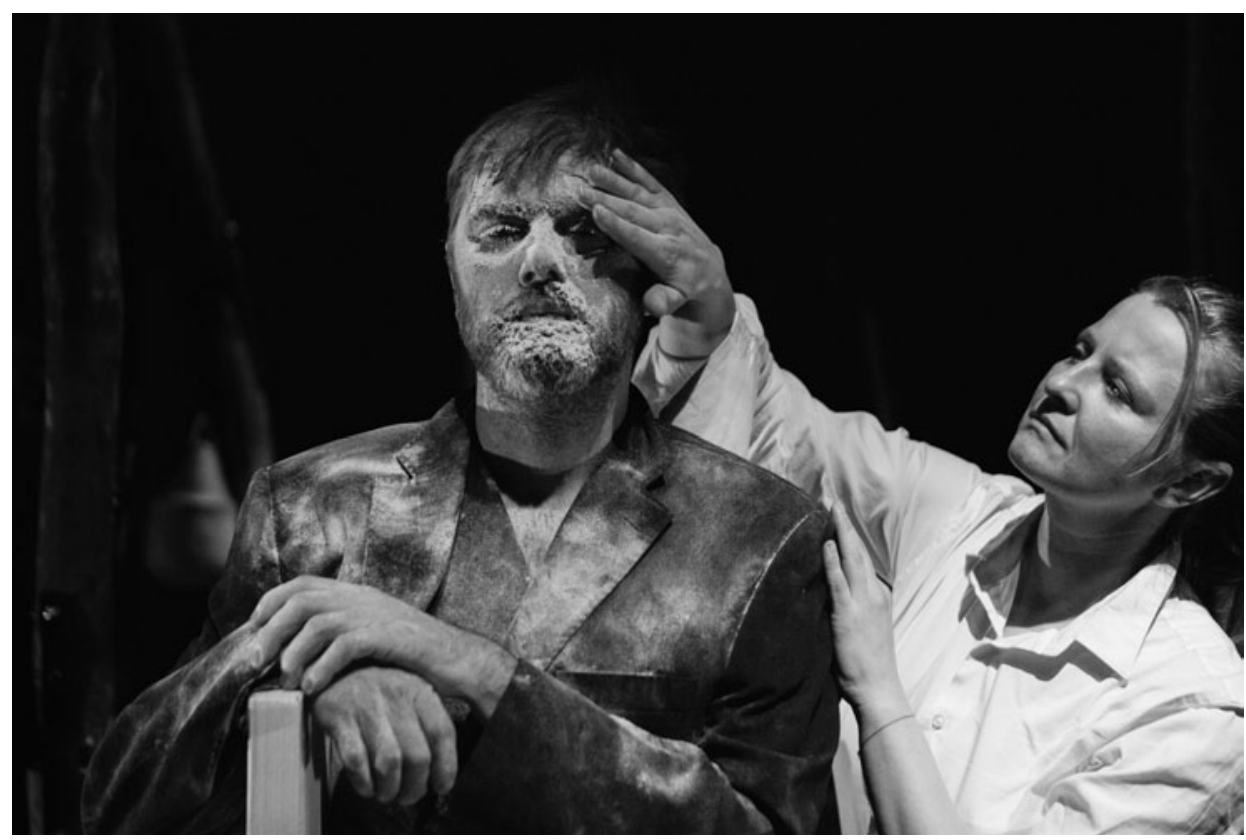

Team of authors: Pastoral Symphony. Theatre Pôtoň, Bátovce, premiered on 13 April 2019 in Bátovce. Direction Iveta Ditte Jurčová. From left Róbert Nižník (Ondrej), Ela Lehotská (Mother). Photo by Radovan Dranga. Theatre Pôtoň archives.

lutely stuck in the tree, thus making the final point to the human torment on earth. The recording of the sound of rain washed everything cathartically, then came darkness and silence.

\section{Musicality in stage production}

Pastoral Symphony offered spectators a number of possibilities to perceive the production. The previous chapter explained the process of perception. The following passage explores the stage piece in greater depth in terms of the intended meaning. ${ }^{15}$

The director and the entire production team made sure that the recipient was able to reach a multiple level of deciphering the set of acting parts. The authors' production shows different elements from Ivan Stodola's play in the role of an almost archaic, universal primordial human experience that appears through different music ritual forms. The musicality of the production arose potentially from any action on the part of an actor on stage. Hence, it acquired a permanent position amidst the structure of parts to which it was integral. It was obvious that the production drew from research into ethnic music. The production featured different forms of practice of pastoral (rural) nature: whip swashing to drive away a bear, aerophones, playing different pipes and fuyara, the repertoire for the weepers from the region of up-

${ }^{15}$ BALME, Ch. Úvod do divadelnej vedy [Introduction to Theatre Studies], p. 104. 
per Liptov, polyphonic singing of the ancient Slavic Lord's Prayer. The authors used music language to articulate universal situations weaved from archaic layers of folk culture (folk music instruments, items, songs, etc.). They drew particularly on the folk culture of Liptov (the valley Demänovská dolina) where the dramatic source text by Ivan Stodola was set. The production was based on opaque, ephemeral lightings that touched largely on the elements of collective unconsciousness. Elsewhere, ritual theatre emerged. The collective improvisations by actors and actresses thus created a refined sonoric - music structure where the harshness of the mountain element intertwined with the fragmentary lyric flashes. The result was fragmentary structured production with major connotative expression - the refined music-image symphony on the edge of ethereal lyricism. Within the extensive parts the spectator ends up in intense encounter with concrete scenes, realising their ephemeral nature. Within the powerfully associative structure general themes of pastoral symphony thus evolved: death, love, home, parenthood, mother and child relationship, concerns about a beloved son, repatriation, pastoral context, beast and man, etc.

Iveta Ditte Jurčová experimented with images and associations in a distinctive gesture, physical communication language that draws on the musicality of the stage piece. Her production was largely associative (in terms of sound and image-sound) mediation from which the essences of the story arch-narrative emerged smoothly. ${ }^{16}$ The spectator just followed its opaque outlines and/or ephemeral contours of human predicament. The director used collective acting improvisation to unveil palpably resonating and synchronising human articulations of universal images as certain anthropological constants. She sought the condensed reservoir of human wisdom and articulated collective experience largely in folk culture. In sophisticated material she captured its ancient, archaic layers, forms and structures. The ritual forms in the songs from the pastoral context of upper Slovakia offered the basis for idiosyncratic impressive scenes that also manifested Ditte Jurčová's directorial poetics which accentuates the visual element (i.e. costumes and set design).

The folk material in the production was transformed in part - it did not appear in direct, illustrative quotation, but was rather freely integrated in individual acting parts. The actors largely improvised with folk instruments (different music instruments and folk items), thus following the authentic level of the universal experience of the testimony that was reinterpreted multiple times. The authors did not attempt to imitate the folk artifact. Instead, they aimed to capture it in its authentic, natural position. The vibrations of folk pipes, fuyara, accordion, whip cracking, reproduced sound of a real-life weeper from Liptov as well as the polyphonic singing were suddenly presented in an abstract, naked form - as autonomous musical forms. The performers experimented with them and gradually integrated them into their acting parts.

${ }^{16}$ As Mariana Čechová et al. suggest: “... it is a term used to define motives that mediate rudimentary proto-stories and basic 'ideological archetypes'." See ČECHOVÁ, M. et al. Osnovné tematické algoritmy v slovesnom umení (s intersemiotickými a interdisciplinárnymi presahmi) [Comprehensive Theme Algorithms in Verbal Art (with Intersemiotic and Interdisciplinary Interconnection)]. Nitra : Univerzita Konštantína Filozofa v Nitre, 2016, p. 155. 


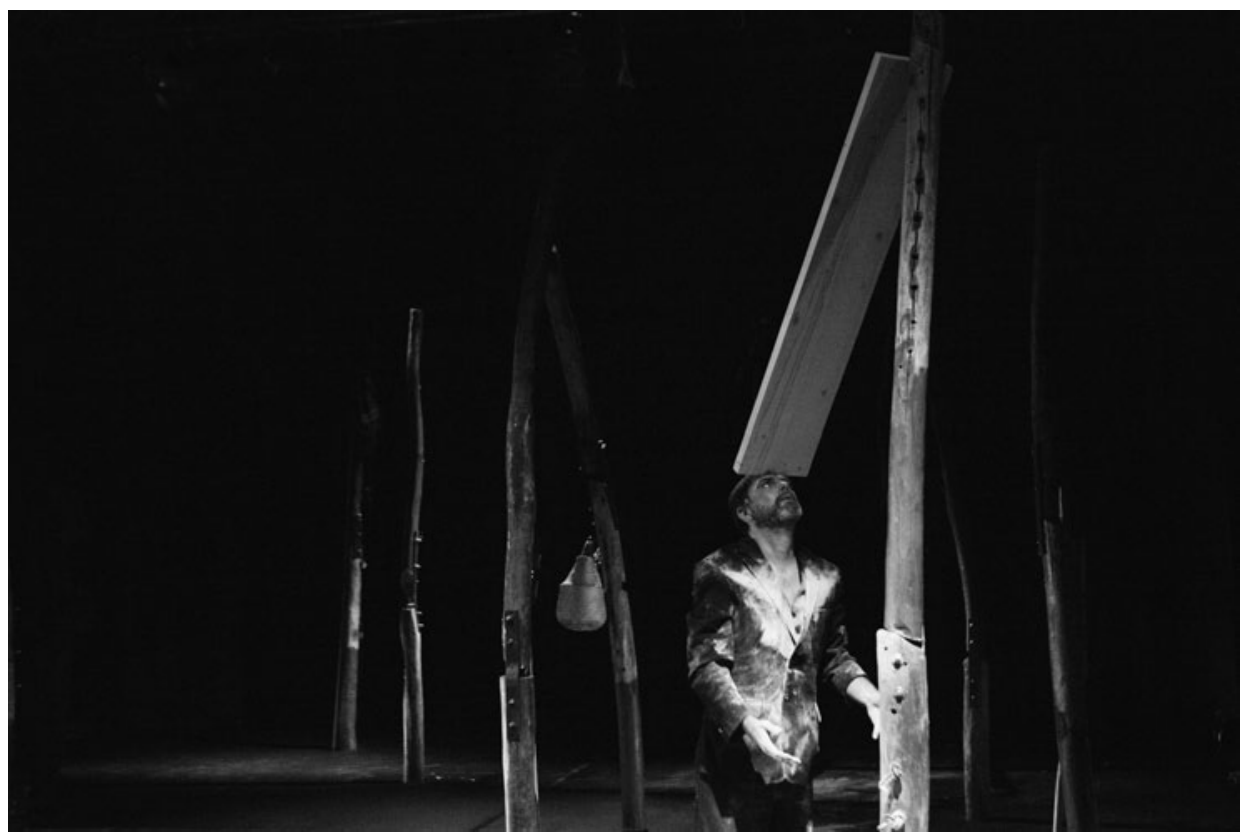

Team of authors: Pastoral Symphony. Theatre Pôtoň, Bátovce, premiered on 13 April 2019 in Bátovce. Direction Iveta Ditte Jurčová. Róbert Nižník (Ondrej). Photo by Radovan Dranga. Theatre Pôtoň archives.

\section{Images and their depictions}

The previous part suggested that the unifying story in the production appeared gradually, in certain linearity, as if shining through. Likewise, the dominant characters of the narrative formula and/or the narrative algorithm appeared gradually: chief shepherd Ondrej Muranica (Róbert Nižník), his wife Eva (Natália Puklušová), assistant shepherd (Lubomír Raši), mother (Ela Lehotská), as well as the guide through the entire story - the archetypal character assuming the mask of a bear, seed merchant, etc. (Lubo Bukový/Filip Jekkel). They gradually created more elaborate prototypes that clearly resembled the dramatic characters abstracted from Stodola's play, or other adaptations of the story for television and film. The actors largely presented multiple conflict situations in their roles. They embodied a resolute struggle with themselves in quest for universal values: home, motherhood, parenthood, patriotism, identity, extirpation, love, death. The scenes with multiple associative message and reach emerged around these framework themes. Not only the actors transformed the themes from Stodola's popular source text, but, in line with the collective creative work, they also created autonomous, universally comprehensible stage parts. In other words, using the drama source text as a basis, they let their own immanent story germinate.

Ultimately, Stodola's play merely offered a cushion for the basic thematic framework for an independent variability of their acting arising from collective improvisation. The team creatively confronted the dominant presence of archetypal situations 


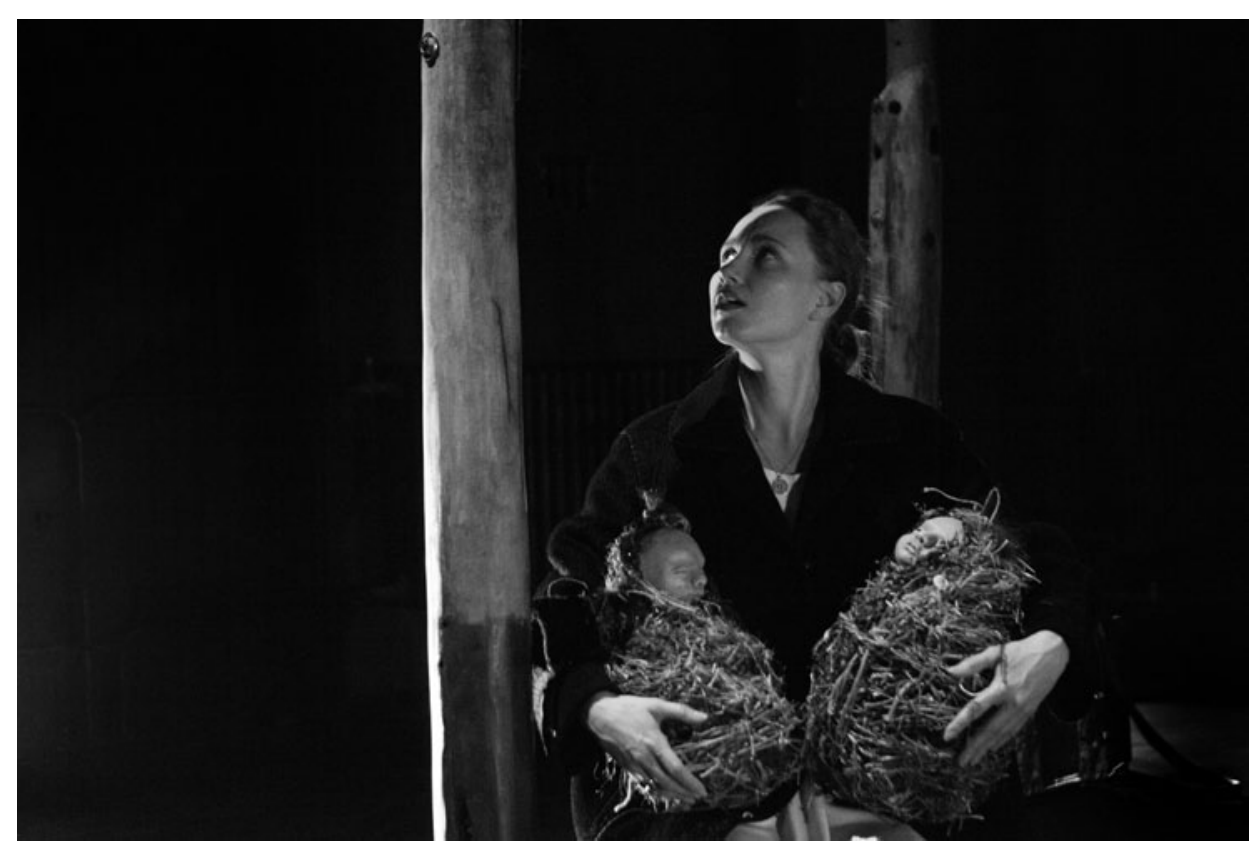

Team of authors: Pastoral Symphony. Theatre Pôtoň, Bátovce, premiered on 13 April 2019 in Bátovce. Direction Iveta Ditte Jurčová. Natália Puklušová (Eva). Photo by Radovan Dranga. Theatre Pôtoň archives.

generously offered by Ivan Stodola in his play. Pastoral Symphony features motives of repatriation, homecoming of an allegedly deceased character, the estrangement of the Americano and his wife, the impossibility of future life on earth, etc. That was specifically transformed in the bear scene (that analogically relates to the departure of Ondrej Muranica and the assistant shepherd Michal overseas to make money to pay for the damages caused by the beast in the sheep farm); and the scene with the sand (reference to the mine disaster that trapped Ondrej in the mine across the ocean); or in Eva's lullaby which alludes to a fairy-tale that Eva tells her children in Act One of Stodola's play.

EVA: Come, children. Once upon a time, there was a lake in our valley. Sky-blue in daytime, dark as coal at night.

ONDREJKO: I haven't seen coal. Is coal black?

MOTHER: Your father has dug out lots of it in America.

EVA (looks, with remorse, at her mother-in-law): Yeah, my child! And this lake was bottomless, people saw wild ducks drown as they dipped in. In the lake - the saying goes - there's a ghost. You won't get scared, will you?

ONDREJKO: I'm not scared, look at Miško! He's dosed off already. He'd be scared. MOTHER: He'd be scared, but you wouldn't. One can't deny one's kin. Your father - the man he was - an ogre, and he feared no one; his father, phew...

EVA: But, mother-in-law! (pulls herself together) Well, they say there's a ghost, though only every fourth year. At night, at full moon, a lady would appears clad 
in white, and whomever she sees there, she addresses by their first name. The lady is said to be such a beauty that people mustn't see her. A seed merchant from Poland heard of it; so he said that, come what may, he had to lay eyes on the beauty. And so, he set off at night with a case on his back filled with seeds he had collected across the country. The Polish seed merchant was awaited to come home; his wife was expecting him, his children were expecting him, yet, he never returned."17

It is obvious that the theme of Eve's legend has become a core and determining theme for the creative team. The production contained both allusions at the quoted legend and its fragments in evolving scenes and symbols. The actors used mostly anti-illusive method to enter the space and to play out the series of actions with a multiple meaning, whilst the director was more interested in the process of the impressive appearance rather than in the concrete scene that evolved. The capacity of actors to bring in their own associations was intensively present throughout the entire storyboard. The process of generating individual acting parts enabled the performers to stimulate their associative memory which often enabled them to reach remarkable levels of universal human experience, ideas and associations in their complexity. Hence, within the storyboard they tried to work variably with the body of their own ideas and to compose authorial profiled scenes. The actors created different variations on a given theme originally taken from Stodola's play. In the process of free, gradually emerging improvisation, they toyed with generating and plastic portrayal of their own memory reservoir. Likewise, immediate experience enabled them to build malleable stage material on the basis of often simple assignments. The performers used associative activity and allowed it to lead them in their very acting creation. One could say that they used the stage to brighten up the associations in individually composed scenes.

\section{Conclusion}

The scenes in Pastoral Symphony focused largely on the pastoral element that has strong regional roots in upper Slovakia (the region of Liptov) where The Shepherd's Wife by Ivan Stodola is set. The basis for individual scenes came, in part, from actors' parts developed from the improvisations with diverse stage and music material. The director Iveta Ditte Jurčová consolidated the created parts into more related scenes that were literally charged with powerful associativeness. The entire production represented a network of such scenes, emerging from opaque ephemerality. The director "installed" the scenes in different places of the acting space: she introduced them in a suggestive way to accentuate their coming and going in a civil alienating form.

The study is an output of the grant project VEGA 1/0282/18 Nature and Evolution of Independent Culture and Art in Slovakia after 1989.

Translated by Lucia Faltin

${ }^{17}$ STODOLA, I. Bačova žena [The Shepherd's Wife], p. 15. 


\section{LITERATURE}

BALLAY, Miroslav. Farma v jeskyni [Farm in the Cave]. Nitra : Ústav literárnej a umeleckej komunikácie FF UKF v Nitre, 2012, 316 p. ISBN 978-80-558-0169-8.

BALME, Christopher. Úvod do divadelnej vedy [Introduction to Theatre Studies]. Bratislava : Divadelný ústav 2018, 350 p. ISBN 978-80-8190-040-2.

ČECHOVÁ, M. et al. Osnovné tematické algoritmy v slovesnom umení (s intersemiotickými a interdisciplinárnymi presahmi) [Comprehensive Theme Algorithms in Verbal Art (with Intersemiotic and Interdisciplinary Interconnection)]. Nitra : Univerzita Konštantína Filozofa v Nitre, 2016, 206 p. ISBN 978-80-558-1115-4.

DITTE, Michal - DITTE JURČOVÁ, Iveta - GODOVIČ, Marek. Bermudský trojuholník v Bátovciach: sila strácania a objavovania [The Bermuda triangle in Bátovce: The Power of Loss and Discovery, an interview]. In kød, 2019, Vol. 13, Issue 5, pp. 3 - 15. ISSN 1337-1800.

LINDOVSKÁ, Nadežda. K otázke ženskej divadelnej réžie. Náčrt stavu a perpektív [On Female Theatre Directing. An Outlive of the Status Quo and Perspectives]. In PODMAKOVÁ, Dagmar (ed.). Generačné premeny a podoby slovenského divadla (od 80. rokov 20. storočia po dnešok) [Generational Transformation and Shapes of Slovak Theatre (from 1980s to the Present Day)]. Bratislava : Ústav divadelnej a filmovej vedy SAV, 2012, pp. 83 - 95. ISBN 978-80-971155-0-0.

KADARE, Ismail. Aischylos, ten vel'ký smoliar [Aeschylus, the Great Schlemiel]. Bratislava : Kalligram 2006, 144 p. ISBN 80-7149-894-7.

Pastierska symfónia. Bulletin k divadelnej inscenácii [Pastoral Symphony. Production programme booklet]. Bátovce : Divadlo Pôtoň, 2019, not paginated.

STODOLA, Ivan. Bačova žena [The Shepherd's Wife]. Bratislava : Tatran 1978, 63 p. No ISBN.

Miroslav Ballay

Katedra kulturológie

Filozofická fakulta Univerzity Konštantína Filozofa v Nitre

Hodžova 1

94974 Nitra

Slovakia

e-mail: mballay@ukf.sk 